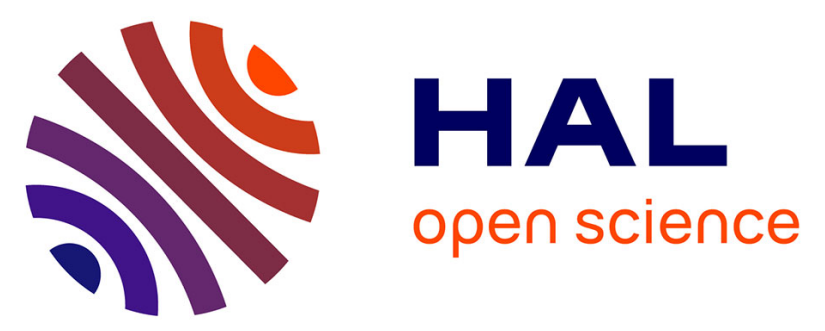

\title{
Characterization of the bond between asphalt layers and glass grid layer with help of a Wedge Splitting Test
}

\author{
Maissa Gharbi, Mai Lan Nguyen, Stéphane Trichet, Armelle Chabot
}

\section{To cite this version:}

Maissa Gharbi, Mai Lan Nguyen, Stéphane Trichet, Armelle Chabot. Characterization of the bond between asphalt layers and glass grid layer with help of a Wedge Splitting Test. 10th International Conference on Bearing Capacity of Roads, Railways and Airfields (BCRRA 2017), Jun 2017, Athènes, Greece. 1517-1524 (Chapter 201), 10.1201/9781315100333-201 . hal-01567490

\section{HAL Id: hal-01567490 \\ https://hal.science/hal-01567490}

Submitted on 27 Jul 2017

HAL is a multi-disciplinary open access archive for the deposit and dissemination of scientific research documents, whether they are published or not. The documents may come from teaching and research institutions in France or abroad, or from public or private research centers.
L'archive ouverte pluridisciplinaire HAL, est destinée au dépôt et à la diffusion de documents scientifiques de niveau recherche, publiés ou non, émanant des établissements d'enseignement et de recherche français ou étrangers, des laboratoires publics ou privés. 


\title{
Characterization of the bond between asphalt layers and glass grid layer with help of a Wedge Splitting Test
}

Gharbi. M., Nguyen. M.L., Trichet S., Chabot. A.,

IFSTTAR, MAST(LAMES), Allée des Ponts et Chaussées CS4 44344 Bouguenais Cedex, France

\begin{abstract}
With the aim of increasing the durability of pavements, the use of glass fiber grid to reinforce asphalt pavements has received a lot of attention in recent years. Performance of the bond between asphalt layers including a glass fiber grid at the interface is among the important parameters to be investigated. In this work, the Wedge Splitting Test (WST) developed by Tschegg (1986) is chosen to evaluate the bond between such material layers. The aim of this study is to characterize the fracture mechanical behavior of the interface through the specific fracture energy $\mathrm{G}_{\mathrm{F}}$. Experiments are performed on specimens extracted from full scale pavement sections. These specimens of significant size $\left(200 \times 200 \times 150 \mathrm{~mm}^{3}\right)$ are prepared with a cylindrical groove instead of a habitual rectangular groove. As recommended in the literature, a slim wedge of $14^{\circ}$ is used to ensure the characterization of the bond in a quasi-pure crack opening mode I. A notch of $5 \mathrm{~mm}$ thick is sawn at the interface between the two material layers to guarantee the initiation of the crack at the interface. Tests are controlled with a constant displacement speed rate of $2 \mathrm{~mm} / \mathrm{min}$ and constant temperatures $\left(\sim 20^{\circ} \mathrm{C}\right)$. A Digital Image Correlation (DIC) technique is used to evaluate and compare the interface crack propagation in two different configurations with and without grid at the interface.
\end{abstract}

\section{INTODUCTION}

Asphalt pavements are characterized by a composite of several layers (LCPC-SETRA, 1994). During its life and due to climate and traffic effects, it presents various phenomena of degradation (LCPC, 1989; Di Benedetto, 1998; Castaneda Pinzon, 2004; Castaneda E. and Such C., 2004). Cracks in pavements cause massive maintenance costs and delaying this phenomenon is the main purpose of all reinforcement solutions. The use of interlayer systems in pavements has become a convenient technology for lifetime prolongation in road construction engineering. This solution has been studied a lot between 1960 and 2000 (De Bondt, 1999; Vanelstraete, A and Franken, L., 1997 \& 2000) in order to delay the reflective cracking phenomena. It is coming back nowadays with more attention from the pavement community as efficient reinforcement solutions for pavements (Kerzhero, 2011; Artières et al., 2012; Hornych et al., 2012; Nguyen et al., 2013; Canestrari et al., 2015; Chabot et al., 2016). However, due to the lack of know-how about designing such types of pavement structures, there is still a debate about their usage. In order to evaluate the use of glass grid fiber and to understand the effectiveness of this system of reinforcement, a French ANR project "SolDuGri” (2015-2018) has been set up by different in- dustrial and laboratory partners. It contains three main axes:

- Better understanding of the solicitations, which the grids are subject to during their implementation, in order to optimize the resistance of the grids in relation to these solicitations,

- Laboratory studies of mechanical behaviors of the interfaces between asphalt layers reinforced with grids,

- Improvement in the design of reinforced pavement by laboratory studies on fatigue behaviors of grids and reinforced asphalt mixtures, as well as by a full scale test using the fatigue carrousel de l'Ifsttar.

The study described in this paper is part of the second axis of this project which aims to evaluate interface bonding in pavement made with or without grids. In this work, the Wedge Splitting Test (WST) developed by Tschegg (1986) is chosen to evaluate the bond between glass grid fiber and the asphalt material in a quasi-pure opening Mode I. This test is applied in static condition in order to determine the specific fracture energy. The bond properties and the crack resistance of interfaces between asphalt layers and glass grid fiber layers are examined and compared with those of asphalt layers without a grid. In this paper materials and specimens preparation are firstly presented. The test method adapted for this study is then explained. First results of the frac- 
ture energy obtained in this study are presented and discussed. The importance of the research introduced with substantial conclusions is stated in the last section.

\section{MATERIALS AND TEST METHOD}

In this study, we choose to test specimens coming from a large scale test field constructed at IFSTTAR Nantes.

\subsection{Materials}

The base and cover layer are made of a bituminous material BBSG according to the European standard EN 13108-1. It has a maximum aggregate size of $10 \mathrm{~mm}$ and a bitumen content $(35 / 50$ penetration grade) of $5.6 \%$ by the weight of the mix. A tack coat is used and is made of a classical cationic rapid setting bitumen emulsion, classified as C69B3 according to EN 13808. Bituminous air content and elastic modulus are respectively aimed to be between 7\% and $9 \%$ and about $5400 \mathrm{MPa}\left(\right.$ at $15^{\circ} \mathrm{C} 10 \mathrm{~Hz} ; \mathrm{v}=$ 0.35) (LCPC-SETRA, 1994). It is aimed to apply about $300 \mathrm{~g} / \mathrm{m}^{2}$ of residual tack coat for section without grid and about $500 \mathrm{~g} / \mathrm{m}^{2}$ for the other sections with a grid.

The geogrid used as reinforcement is the glass fiber grid G1 (Chazallon et al., 2017). This grid is an elastic composite of warp and filling yarns and a nonwoven part of polyester fiber (mesh size of $40 \times 40$ $\mathrm{mm}^{2}$ ) (Figure 1). Its mechanical resistance at failure is equal to $50 \mathrm{kN} / \mathrm{m}$.

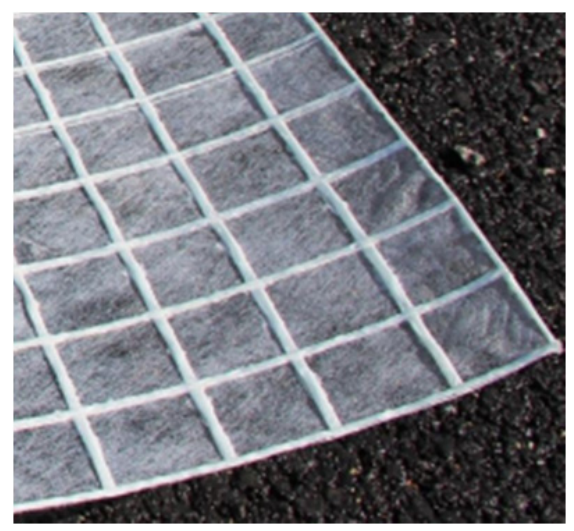

Figure 1. Glass fiber grid G1.

\subsection{Construction}

A large scale test field of $30 \mathrm{~m} \times 3 \mathrm{~m}$ (Figure 2) is prepared for specimen creation using standard road work equipment and glass fiber grid installation techniques. The construction of the test field was carried out from 24th to 25th November, 2015. For the two days, the temperature was around $12^{\circ} \mathrm{C}$ with around $90 \%$ of humidity. The P1Section is prepared with a double-layered asphalt pavement without the grid and the P3 section is prepared with the grid. In both sections two layers having a thickness of 100 $\mathrm{mm}$ each are achieved. For construction reasons, each layer of the two layers contains two under layers (Figure 3 ). From each section, slab of $280 \times 480$ $\times 250 \mathrm{~mm}$ will be cut in order to be sawn into two samples (Figure 2). For the P3 section an amount of more than $500 \mathrm{~g} / \mathrm{m}^{2}$ of residual binder were spread at the interface before the application of the grid with the application of a supplementary quantity after its application (Figure 4).

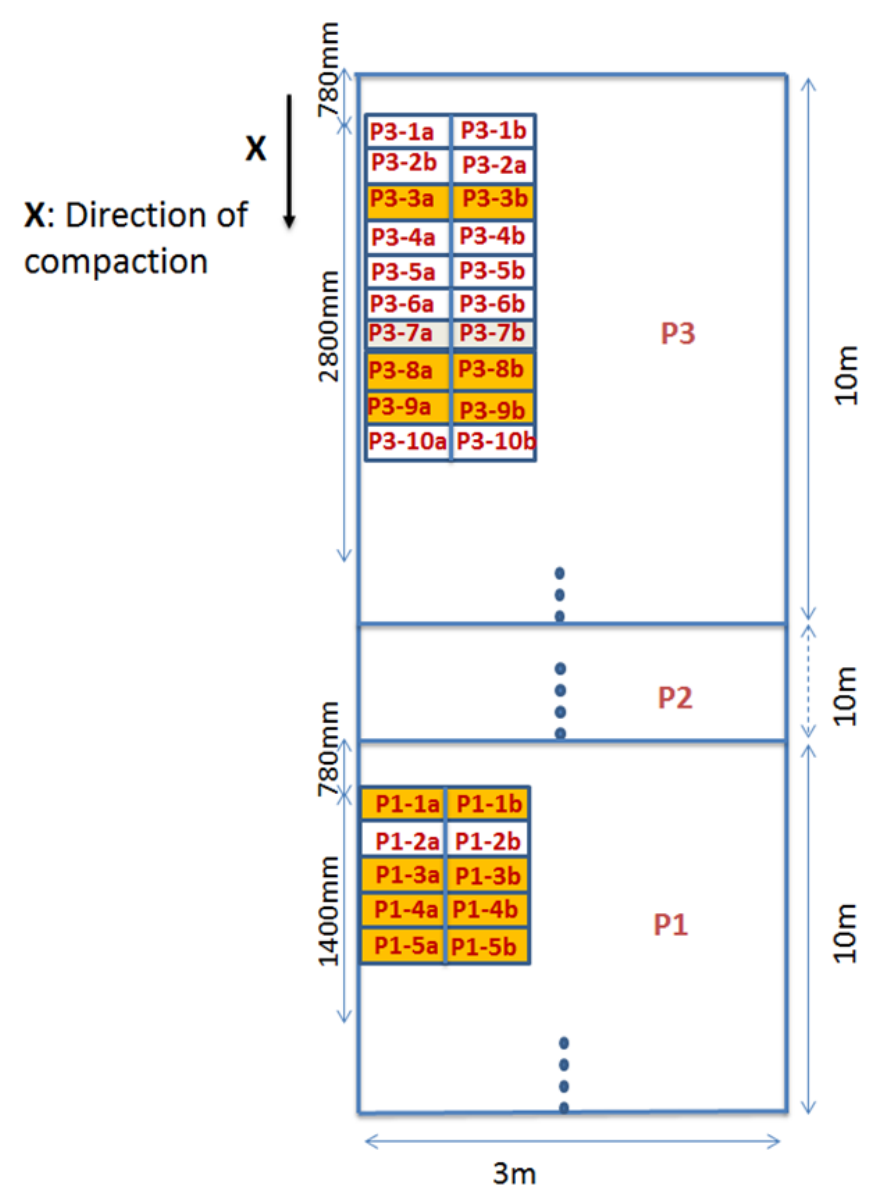

Figure 2. Test sections of the ANR SolduGri project.

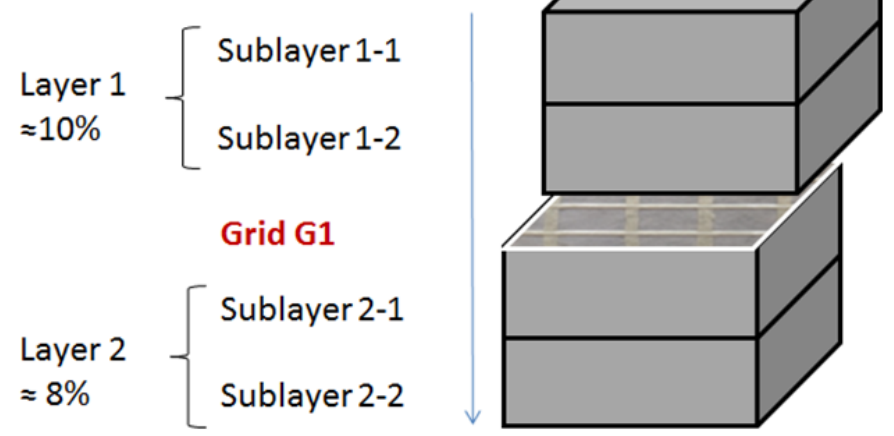

Figure 3. Air content for reinforced and unreinforced specimen. 


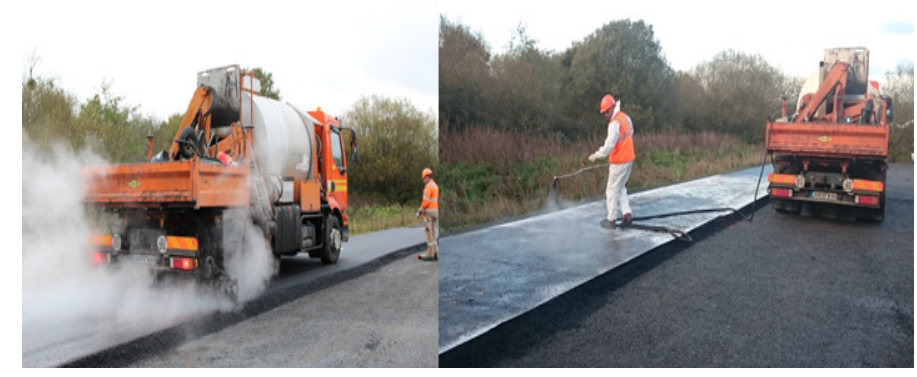

Figure 4. Application of tack coat.

\subsection{Sample preparation}

For each slab extracted from the experimental section, two cubes are cut out to obtain two samples of dimension $(\mathrm{H} \times 200 \times 150 \mathrm{~mm})$. Specimens are large enough to obtain a minimum of nine fiber glass meshes for the reinforced specimens. Elastic modulus is found equal to $11000 \mathrm{MPa}$ at $15^{\circ} \mathrm{C} 10 \mathrm{~Hz}(\mathrm{v}=$ 0.35 ). The indexes "a" and "b" are noted for specimens situated respectively close to and further from the edge of the experimental sections (Figure 2). Figure 3 shows schematically the different layers for specimens with the air content reached in reality after construction.

To prepare the WST specimen in a quite easy way, a semi-circular groove is made by coring, replacing the standard rectangular groove of this test (Gharbi et al., 2017). A starter notch of $5 \mathrm{~mm}$ in width is introduced by sawing at the bottom of the semicircular groove (Figure 5). To have sufficient space for load transmission pieces which are made with steel materials and the wedge, the groove diameter is chosen equal to $56 \mathrm{~mm}$. The size and dimensions of the wedge splitting specimen are given in Figure 5.

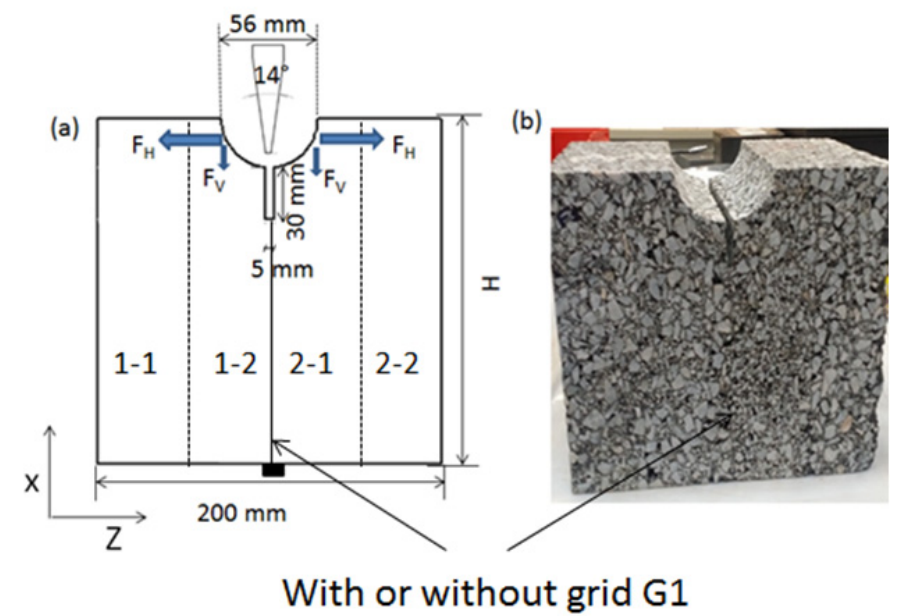

Figure 5. The WST test (a) Dimensions of our specimen shape (b) bituminous specimen (Gharbi et al., 2017).

\subsection{Test method}

The WST was proposed by Linsbauer \& Tschegg (1986) and developed by Bruhwiler \& Wittlmann
(1990). It is a simple test method used for the fracture mechanical characterization of materials. A vertical force $F_{M}$ generated by the testing machine is transmitted from the wedge to the specimen by means of load transmission pieces and transformed into a much higher horizontal force $F_{H}$ and a low vertical force $F_{V}$. The horizontal force $F_{H}=$ $F_{M} / 2 \operatorname{tg}(\alpha)$, "where " $\alpha$ " is the half of the wedge angle, leads to mode I tensile fracture and results in a splitting for the specimen. Here, the wedge angle is chosen equal to $14^{\circ}$ (Figure 5a). The magnitude of the splitting force is determined by the equation $F_{S}=2 F_{H}$. Figure 5a shows the principle of the test method for cubical-shaped specimens coming from the pavement sections. One of the surfaces of the bilayer specimen is prepared with speckled pattern for further DIC analysis (Figure 6a). The other one is prepared with a whiting chalk powder to visualize the crack propagation (Figure 6b). Load transmission pieces contain movable rollers in order to minimize the friction forces. Two LVDT sensors (with a measured range of $10 \mathrm{~mm}$ ) are placed at the end of the starter notch (Figure 6b) to measure horizontal displacements. LVDT 1 is used to measure the crack opening displacement " $\delta$ ". The WST test makes possible the determination of fracture mechanics properties of tested materials such as the specific fracture energy $G_{F}$. The energy $S_{A}$ required for the fracture of the specimen is calculated from the area under the $\mathrm{F}_{\mathrm{S}}-\delta$ curve (Tschegg et al., 1995a). The specific fracture energy $G_{F}$ is obtained, by Equation 1 .

$G_{F}=\frac{S_{A}}{S_{F}}$

Where $\mathrm{S}_{\mathrm{F}}$ is the final fracture area of the specimen. Tests are performed with a mechanical testing machine Zwick with a load capacity of $2.5 \mathrm{KN}$, and a cross head speed of $2 \mathrm{~mm} / \mathrm{min}$ according to the literature (Tshegg et al., 1996). All tests are realized at ambient temperature (approximately $20^{\circ} \mathrm{C}$ ). 
(a)

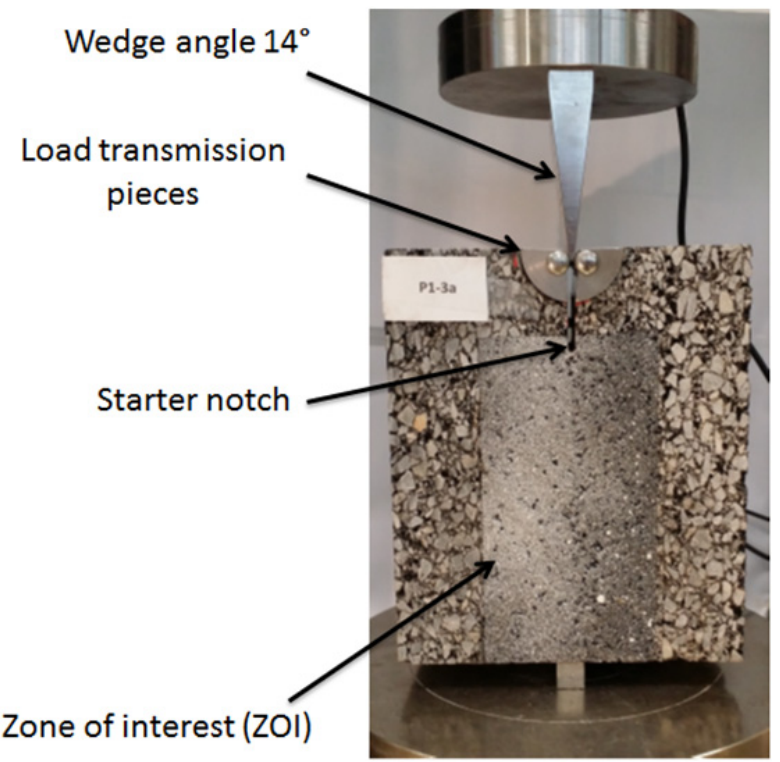

(b)

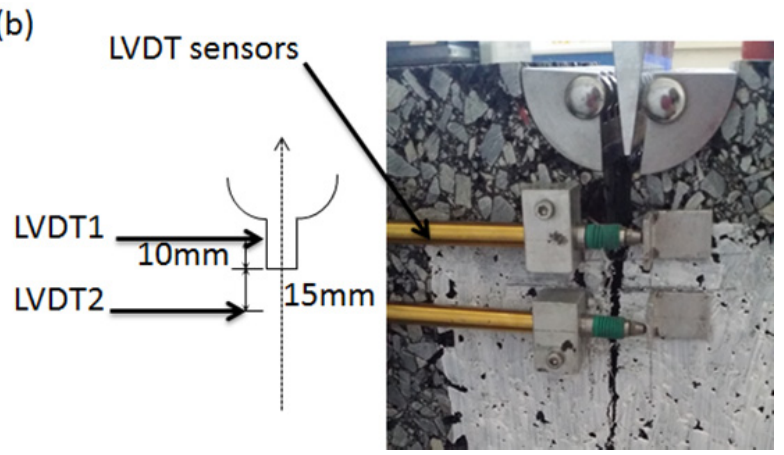

Figure 6. The adapted WST test used in this project (a) Principle of the test (b) LVDTs' positions.

\section{RESULTS AND ANALYSIS}

\subsection{Fracture surface observation}

For reinforced specimens with glass grid fiber coming from the P3 section (Figure 2), we noted, after the WST tests, that a total de-bonding occurred between two bituminous layers stuck with an important quantity of tack coat. Figure 7 shows the fracture surface for these tested reinforced specimens. Three types of de-bonding mode of the grid in the fracture surface occurred. The first is when the grid still bonded on the bottom surface of layer 1 (Figure 7a, c). The second is when the grid bonded on the top surface of layer 2 (Figure 7d). The third is when the grid bonded to both layers (Figure 7b). (a)

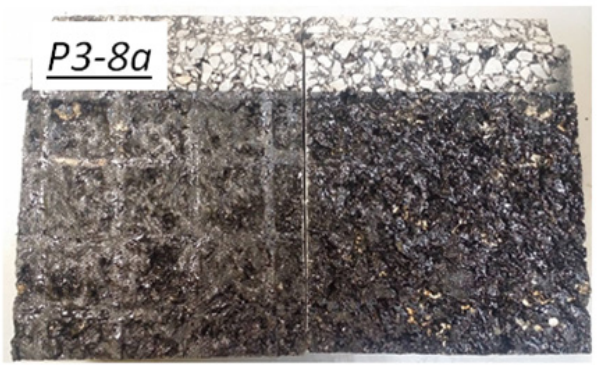

(b)

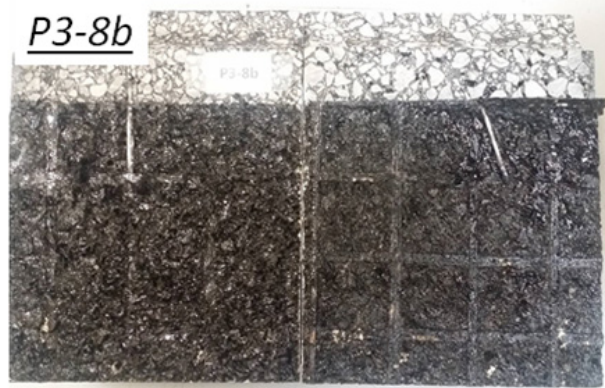

(c)

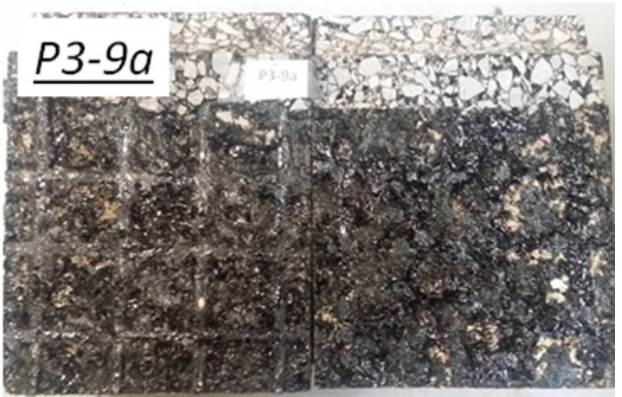

(d)

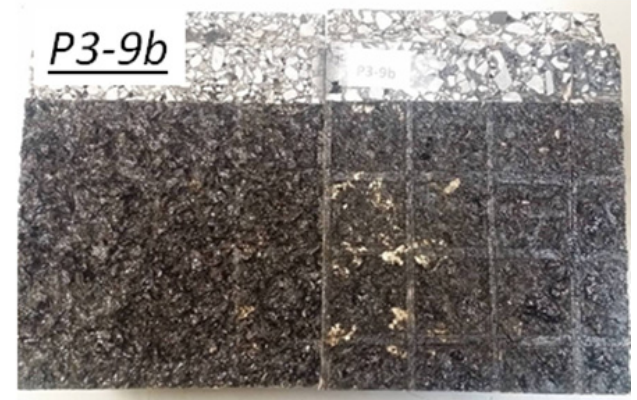

Figure 7. Fracture surfaces of reinforced specimens.

The total fracture of the specimen was not achieved for specimens without a grid. Actually, the key stage for a successful test is the implementation of different elements of the WST test (load transmission pieces and the wedge). In the case where the wedge is blocked and its transition into the specimen through load transmission pieces can be stopped. This problem has been noted for P1-4a specimen (Figure 8$)$. The high thickness of the notch $(5 \mathrm{~mm})$ (Figure 5a) may be one of the problems of the adaptation of this test for materials stemming from real pavement sections. 


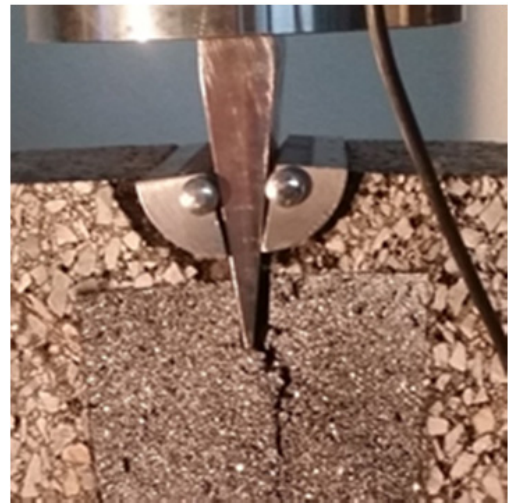

Figure 8. Wedge blocked on the bottom of the notch.

Therefore the real depth of the crack is not quite known for unreinforced specimens. In order to approximate the fracture area of the specimen, $S_{F}$, the real depth of the crack is then visually detected by means of the whiting chalk powder (Figure 9) or with DIC technique.

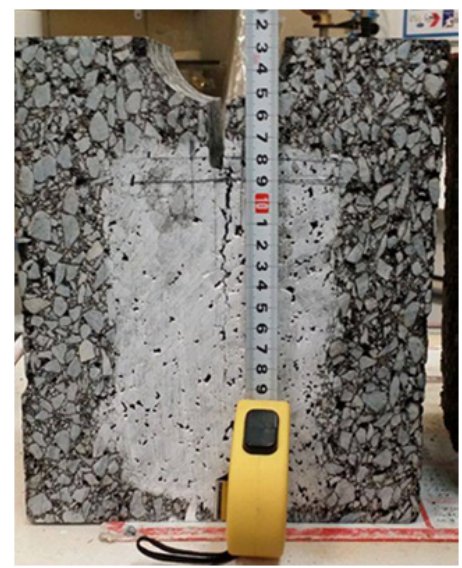

Figure 9. Determination of the depth of the crack using whiting chalk powder.

\section{$3.2 F s$ - $\delta$ curves}

This section illustrates the main findings obtained from the WST test for reinforced and unreinforced samples. The $\mathrm{F}_{\mathrm{S}}-\delta_{L V D T 1}$ curves are initially presented. As mentioned previously, the crack opening displacement $\left(\delta_{\mathrm{LVDT} 1}\right)$ is obtained using the LVDT 1 . WST tests showed stable crack propagation for reinforced specimens. Typical load displacement curves for all reinforced specimens are shown in Figure 10. The different curves exhibit dispersed results. Indeed, one of the main reasons is that the residual binder amount spread at the interface is not quite controlled during the construction.

As published from others mode I tests results using the interface Bond Test (Hakimzadeh et al., 2012) with fracture surface of about twice as small as our fracture surface, the amount of the tack coat also plays a role on the performance of the interface bond for bituminous materials. It is highlighted that for a smaller application amount of the tack coat, a small value of the specific fracture energy is observed, for a test temperature varying between $12^{\circ} \mathrm{C}$ and $25^{\circ} \mathrm{C}$.

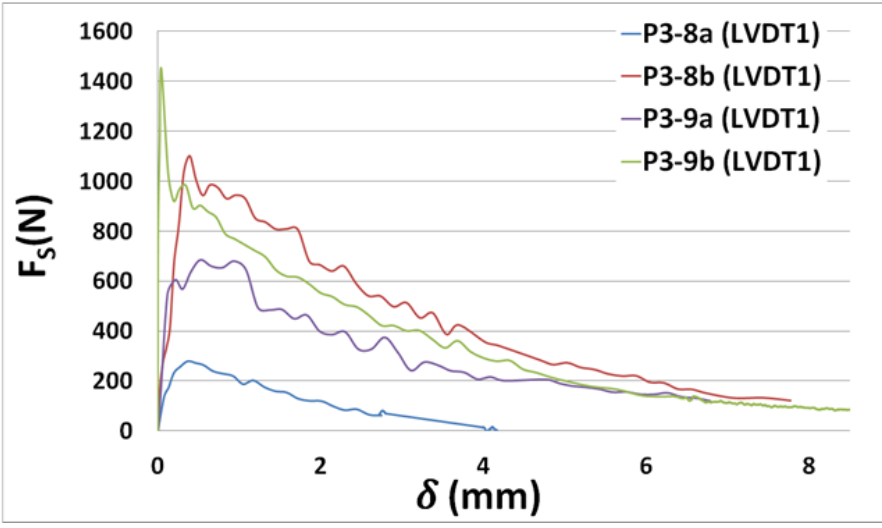

Figure 10. Load displacement curves for reinforced specimens $\left(2 \mathrm{~mm} / \mathrm{min}, \mathrm{T} \approx 20^{\circ} \mathrm{C}\right)$.

Due to problems described in the previous section (Figure 8) tests on unreinforced specimens are stopped at an advanced stage before a total delamination of the interface. This explains the shape of $\mathrm{F}_{\mathrm{S}}-\delta$ curve shown in Figure 11, where the load is not decreased until $0 \mathrm{~N}$.

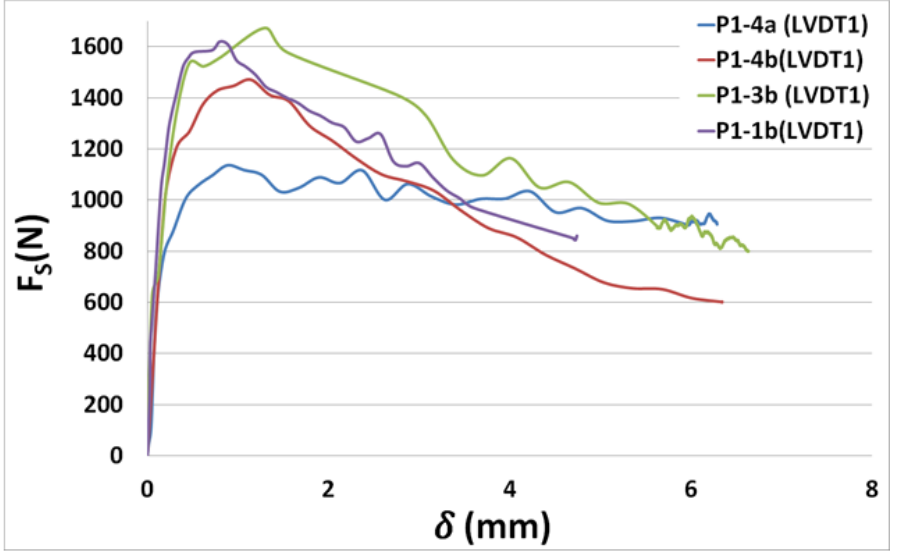

Figure 11. Load displacement curves for unreinforced specimens $\left(2 \mathrm{~mm} / \mathrm{min}, \mathrm{T} \approx 20^{\circ} \mathrm{C}\right)$.

Globally the results are dispersed for unreinforced and reinforced specimens. In fact, specimens noted "a" situated far from the edge of the pavement sections (Figure 2) show a higher splitting load than the other specimens close to the edge. It is may be explained by the difference in compaction conditions for each part of the pavement during construction and the use of an uncontrolled residual binder content.

By comparing curves in Figure 10 and 11 on four specimens of each configuration, we note that the maximum loads of non-reinforced samples are generally more important than those for reinforced samples. These comments will be improved with more tests in the future. 


\subsection{Application of DIC}

With the aim of deepening the knowledge of crack propagation in such a test, a digital image correlation (DIC) technique is used. This technique has been deployed since 1980 in order to deepen knowledge about the determination of crack opening (Sutton et al., 1983; Roux et al., 2009; Hild and Roux, 2006; Pop et al., 2011, Buttlar et al., 2014). The principle of this technique is to follow the positional changes of a speckled pattern located on the sample surface. The speckled pattern is typically artificial by applying water based black and white paint (Figure 6a).

Let's consider a reference image defined as $f$ which is acquired at the initial stage. After instant $t$, a shifted image $g$ will be created by an in plane displacement field $u(x)$ and defined by $g(x)=f(x+$ $u(x))+b(x)$, where $\mathrm{b}(\mathrm{x})$ is noise induced by image acquisition (Hild and Roux, 2006). The numerical correlation consists of minimizing the correlation function between the function $f$ and $g$.

In this study, the software Correla 2012 developed by the University of Poitiers is employed (Dupré et al., 2012). The images obtained contained $1388 \times 1038$ pixels. The zone of interest (ZOI) defined in DIC analysis is illustrated in Figure 6(a). The subset size $64 \times 64$ pixels is chosen with vertical and horizontal gaps of 1 pixel. The horizontal factor scale is about $0.21 \mathrm{~mm} /$ pixel. The bilinear image interpolation algorithm was used for sub-pixel evaluation. Displacement $\delta_{D I C}$ is also determined by a DIC technique. The principle is to choose two points in the image (Figure 12) which correspond to the position of the LVDT1 and determine the displacement between those two points during a test by using Corella 2012.

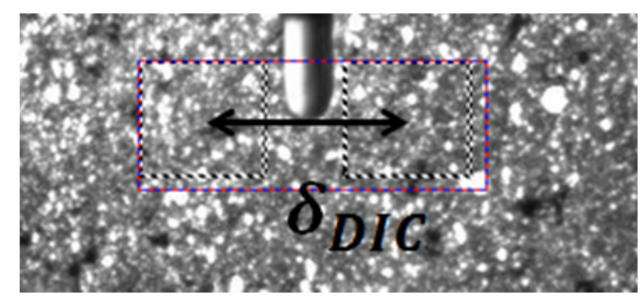

Figure 12. Determination of $\delta_{D I C}$.

Assuming that the WST test is a quasi-pure mode I test, only displacement along $\mathrm{z}$ coordinates are studied (Figure 5). Figure 13 and 14 show an example of $\mathrm{F}_{\mathrm{S}}-\delta_{\text {DIC }}$ curves compared to $\mathrm{F}_{\mathrm{S}}-\delta_{\mathrm{LVDT} 1}$ curves for an unreinforced and reinforced specimen.

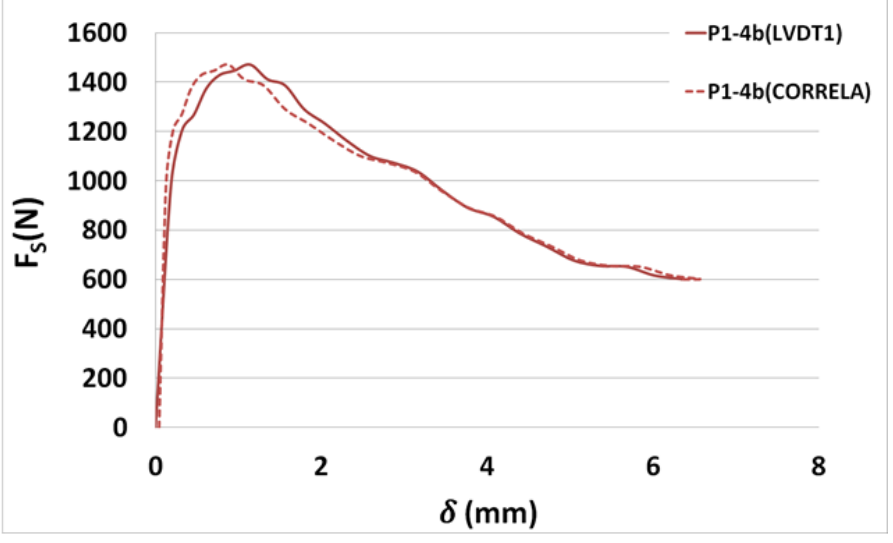

Figure 13. Comparison between load - displacement curves from LVDT1 and load - displacement curves from DIC for the unreinforced specimen P1-4b.

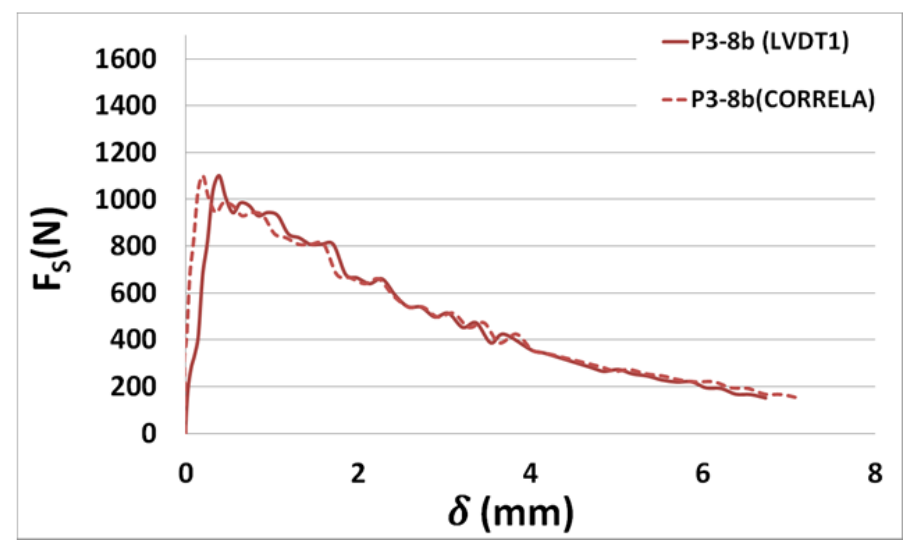

Figure 14. Comparison between Load displacement curves from LVDT and Load displacement curves from DIC for the reinforced specimen $\mathrm{P} 3-8 \mathrm{~b}$.

With the DIC technique, it is also possible to identify the depth of the crack at final stage $\left(a_{c}\right)$. Hence the specific fracture energy is calculated with the actual fracture area $S_{F}$. Figure 15 explains the method used to determine the crack depth, $a_{c}$ is the crack depth calculated from Equation (2):

$a_{c}=\left(U_{x}+(n-1) \times 64\right) \times t$

Where $\mathrm{t}=0,18 \mathrm{~mm}$ is the vertical scaling coefficient for 1 pixel, and $U_{x}$ can be defined as follows

$U_{x}=\sum_{i=1}^{n} u_{i}$

The final depth of crack corresponds to the position $P n$ where no change in position is observed. 


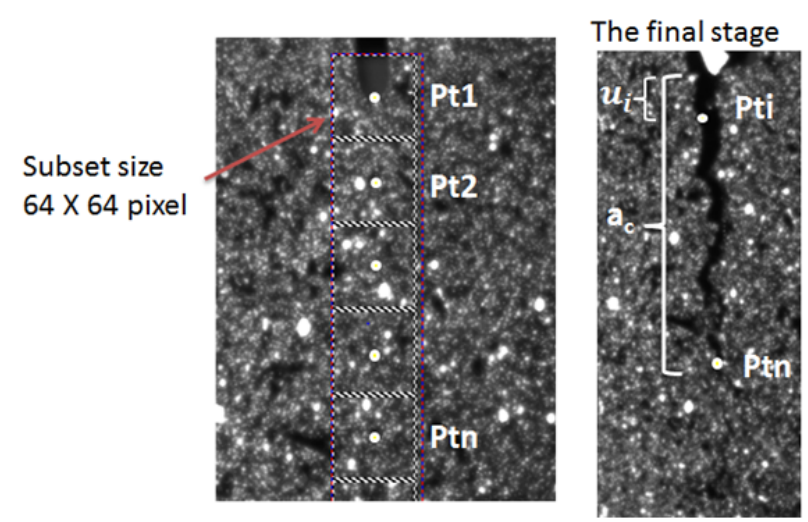

Figure 15. Determination of crack depth by calculate the sum of the distances between the first (Pt1) and the final positions (Ptn).

So, for unreinforced specimens the real crack depth is calculated according to a DIC method described previously. $\mathrm{S}_{\mathrm{A}}$ and $\mathrm{S}_{\mathrm{ADIC}}$ are the energy required for the fracture of the specimen which are calculated respectively from $\mathrm{F}_{\mathrm{S}}-\delta_{D I C}$ curves and $\mathrm{F}_{\mathrm{S}}-\delta_{\text {LVDT1 }}($ Table 1$)$. Table 1 gives an idea about different results found for only 4 specimens for each type of sample. The specific fracture energies are then calculated through Equation 1. Results from LVDT and DIC method are close to both reinforced and unreinforced specimens. Table 1 shows that the lowest value of the fracture surface $\mathrm{S}_{\mathrm{F}}$ corresponds to the bigger value of the specific energy $\mathrm{G}_{\mathrm{F}}$.

Comparing results for reinforced and unreinforced samples on only 4 specimens for each one, results show that the use of glass grid fiber reduces the bond performance between layers.

Table 1. WST's results for tested specimens

\begin{tabular}{c|cccccc}
\hline $\begin{array}{c}\text { Speci- } \\
\text { mens }\end{array}$ & $\begin{array}{c}S_{F} \\
\left(m^{2}\right)\end{array}$ & $\begin{array}{c}F_{\text {Smax }} \\
(N)\end{array}$ & $\begin{array}{c}S_{A} \\
(N . m)\end{array}$ & $\begin{array}{c}S_{A D I C} \\
(N . m)\end{array}$ & $\begin{array}{c}G_{F} \\
\left(J / m^{2}\right)\end{array}$ & $\begin{array}{c}G_{F D I C} \\
\left(J / m^{2}\right)\end{array}$ \\
\hline P1-1b & 0.013 & 1619 & 5.67 & 5.34 & 445 & 419 \\
P1-3b & 0.014 & 1673 & 8.07 & 6.8 & 594 & 501 \\
P1-4a & 0.017 & 1136 & 6.23 & 6.22 & 361 & 360 \\
P1-4b & 0.011 & 1471 & 6.26 & 6.27 & 596 & 597 \\
& & & & $\mathbf{G}_{\text {Faverage }}$ & $\mathbf{4 9 9}$ & $\sim \mathbf{4 6 9}$ \\
P3-8a & 0.022 & 279 & 0.50 & 0.49 & 23 & 22 \\
P3-8b & 0.022 & 1101 & 3.46 & 3.36 & 161 & 166 \\
P3-9a & 0.021 & 684 & 2.17 & & 102 & 144 \\
P3-9b & 0.021 & 1452 & 3.13 & 3.08 & 146 & $\sim \mathbf{1 1 1}$ \\
\hline
\end{tabular}

\section{CONCLUSION}

In this paper, the wedge splitting test was successfully applied with the aim of comparing the bond performances between asphalt layers with and without a glass grid at the interface. The major challenge was the adaptation of the WST test to these types of materials with an important geometry coming from road construction and the research of the crack length. On only four specimens fracture energy of bitumen reinforced with a glass grid fiber was experimentally investigated with the WST test.

The conclusions obtained from this first study are as follows:

1. With glass grid fiber as reinforcement an abatement of the specific fracture energy for bituminous material, up to $80 \%$ compared to unreinforced bituminous materials, has been achieved.

2. Digital Image Correlation DIC technique is appropriate to find the depth of the crack.

It should be noted that these conclusions were drawn based on the initial results from this study, which only used one type of grid and only four specimens for each case. As well as for the work done in mixed mode condition (Chabot et al., 2013), a modelling step is needed to better understand the de-bonding phenomena between asphalt layers and glass grid layer. In addition to this, characterizing the bond of such interfaces, under different climate conditions such as different temperatures from cold to warm and under a water bath or not, similar to (Chabot et al., 2016), is one of the principal objectives of this project.

\section{ACKNOWLEDGEMENTS}

Authors would like to thank the ANR SolDuGri project for funding this interesting subject, Thomas Lenoir, Jean-Pierre David and Jean-Luc Geffard for helping in this study, Sébastien Buisson and Jerome Demoncheaux for the fabrication of WST specimens and Pierre Hornych for organization of the project.

\section{REFERENCES}

Artières, O., Bacchi, M., Bianchini, P., Hornych, P.,\&Dortland, G. 2012. Strain measurement in pavements with a fibre optics sensor enabled geotextile, Proceedings of the 7th international RILEM conference on cracking in pavements, Delft.

Bruhwiler E. \& Wittmann F. H. 1990. The wedge splitting test, a new method of performing stable fracture mechanics tests. Engineering Fracture Mechanics, 117-125.

Buttlar, W.G., Hill, B.C., Kim, Y.R., Kutay, M.E., Millien, A., Montepara, A., Paulino, G.H., Petit, C., Pop, I.O., Romeo, E., Roncella, R., Safavizadeh, S.A., Tebaldi, G., Wargo, A. 2014. Digital image correlation techniques to investigate strain fields and cracking phenomena in asphalt materials, Mater. Struct 47 : 1373-1390.

Castaneda Pinzon, E.A. 2004. Contribution de méthodes non destructives à l'évaluation de l'effet de l'eau sur les enrobés bitumeux, PhD Thesis Nantes University, France.

Castaneda, E., Such, C. 2004. Evaluation of moisture sensitivity of bituminous mixtures by a complex modulus approach, Transportation Research Record, Journal of the Transportation Research Board, 1891, TRB, National Research Council, Washington D.C 62-67.

Canestrari, F., Belogi, L., Ferrotti, G., Graziani, A. 2015. Shear and flexural characterization of grid-reinforced asphalt 
pavements and relation with field distress evolution. Mater Struct 48: 959. doi:10.1617/s11527-013-0207-1

Chabot, A., Buttlar, B., Dave, E., Petit, C., Tebaldi, G., 1st ed. 2016. Cracking and Debonding in Pavements" - 8th RILEM International Conference on Mechanisms of Cracking and Debonding in Pavements Springer Series: RILEM Bookseries, Vol. 13, ISBN 978-94-024-0866-9, DOI: 10.1007/978-94-024-0867-6

Chabot, A., Hun, M., Hammoum, F. 2013. Mechanical analysis of a mixed mode debonding test for "composite" pavements. Construction and Building Materials 40: 1076-1087. DOI: 10.1016/j.conbuildmat.2012.11.027.

Chabot, A., Hammoum, F., Hun, M., 2016. Mixed - Mixedmode debonding approach to evaluate water sensibility in bi-layer composite pavements. 8th International conference on Mechanisms of Cracking and Debonding in Pavements (MCD2016), Nantes, France, June 7-9, 2016. A. Chabot et al. (Eds). Springer RILEM Bookseries, 13: 613-618, ISBN: 978-94-024-0867-6. DOI: 10.1007/978-94-024-0867-6 86.

Chazallon, C., Nguyen, T.C., Nguyen, M.L., Hornych, P., Doligez, D., Brissaud, L., Godard, E. 2017. In situ damage evaluation of geogrid used in asphalt concrete pavement. Tenth International Conference on the Bearing Capacity of Roads, Railways and Airfields, Athens.

De Bondt, A.H. 1999. Anti-Reflective Cracking Design of (Reinforced) Asphaltic Overlays. Ph.D Thesis, Delft University of Technology.

Di Benedetto, H. 1998. Modélisation: écart entre état des connaissances et applications, Journée LAVOC, Ecole Polytechnique Fédérale de Lausanne, $23 \mathrm{p}$

Dupré, J.C., Doumalin, P., Valle, V., Brémand, F. 2012. Mode d'emploi du logiciel Correla V2012. Notice d'utilisation $d u$ logiciel.

Hild, F., Roux, S. 2006. Measuring stress intensity factors with a camera: Integrated digital image correlation (I-DIC). C. $R$. Mecanique 334, 8-12.

Gharbi, M., Nguyen, M.L., Chabot, A. 2017. Experimental evaluation of the interface fracture energy for composite pavements. EATA 2017, Dübendorf, June 12th $-14^{\text {th }}$.

Hakimzadeh, S., Buttlar, W.G., Santarromana, R . 2012. Evaluation of Bonding between HMA Layers Produced with Different Tack Coat Application Rates using Shear-type and Tension-type Tests, TRB 2012 Annual Meeting

Hornych, P., Kerzrého, J.P., Sohm, J., Chabot, A., Trichet, S., Joutang, J. L., \& Bastard N. 2012. Full scale tests on grid reinforced flexible pavements on the French fatigue carrousel. Proceedings of the 7th international RILEM conference on cracking in pavements, Delft.

Kerzhero, J.P., Michaud, J.P., Hornych, P. 2010. Enrobé armé de fibres de verre - Test sur le manége de fatigre de l'IFSTTAR, RGRA, vol. (890), pp. 48-51.

LCPC-SETRA, 1994, Guide technique, conception et dimensionnement des structures de chaussée, LCPC-SETRA.

LCPC. 1998. Méthode d'essai $\mathrm{n}^{\circ 52}$, catalogue des dégradations de surface des chaussées.

Linsbauer, H.N., \& Tschegg, E.K. 1986. Fracture energy determination of concrete with cube-shaped specimen's. Zement und Betón, 31: 38-40.

Nguyen M.L., Blanc J., Kerzrého J.P. \& Hornych P., 2013. Review of glass fibre grid use for pavement reinforcement and APT experiments at IFSTTAR, Road Materials and Pavement Design, Vol. 14, No. S1, 287-308.

Octavian Pop, Mamadou Meite, Frédéric Dubois, Joseph Absi. 2011. Identification algorithm for fracture parameters by combining DIC and FEM approaches. International Journal of Fracture 170(2):101-114.

Rigo, J. M. 1993. General introduction, main conclusions of 1989 conference on reflective cracking in pavements, and future prospects. Proc., 2nd International RILEM Confer- ence - Reflective Cracking in Pavements, E \& FN Spon, Liege, Belgium 3-20.

Roux, S., Rethore, J., Hild, F. 2009. Digital image correlation and fracture: an advanced technique for estimating stress intensity factors of $2 \mathrm{D}$ and $3 \mathrm{D}$ cracks. J. Phys. D, Appl. Phys 42 (21) : 214004.

Sutton, M., Wolters,W., Peters,W., Ranson,W., andMcNeill, S. 1983. Determination of displacements using an improved digital correlation method. Image and Vision Computing $1(3): 133-139$.

Tschegg, E. K. 1986. Equipment and appropriate specimen shapes for tests to measure fracture values, AT No. 390328, Austrian Patent Office, Vienna, Austria.

Tschegg, E. K, Tschegg-Stanzl, S. E, Litzka. J, 1996. Fracture behavior and bond strength of bituminous layers. RILEM, 133-142.

Tschegg, E. K., Jamek, M., \& Lugmayr, R 2012. Crack growth behaviour in geosynthetic asphalt interlayer systems. $R M P D, 156-170$.

Vanelstraete, A., Franken, L. 1997. Prevention-of-reflectivecracking-in-pavements, RILEM TC 157 PRC report.

Vanelstraete, A., Franken, L. 2000. On site behaviour of interface system. In: Proceedings of the 4th International RILEM Conference, Ottawa, Canada, 26-30 Mars, 517526. 